\title{
Refugial debate: on small sites according to their function and capacity
}

\author{
Marcin Kiedrzyński ${ }^{1}$ • Katarzyna M. Zielińska ${ }^{1}$ • \\ Edyta Kiedrzyńska $^{2,3} \cdot$ Agnieszka Rewicz $^{1}$
}

Received: 3 April 2017/ Accepted: 3 July 2017/Published online: 20 July 2017

(C) The Author(s) 2017. This article is an open access publication

\begin{abstract}
The occurrence and location of long-term refugia determine the current patterns of biodiversity on Earth. The importance of the refugial debate is certain to increase in response to observed and expected species extinctions caused by climate change. Small areas where species survive outside their core range are important, as unique natural phenomena and model systems for observing the response of species to climate change. They can play a crucial role as potential sources for species recovery in the future or can act as progenitors of a new species. While most authors believe that sites connected with only long-term isolation should be included into the refugium concept, this approach can result in the loss of linkage between the ecological and evolutionary processes taking place during different phases of the species range dynamics. Moreover, the papers often interpret the nature of described phenomena in different ways. In response, the conceptual scheme given in our letter summarises the patterns which occur during species range shift. It proposes an equivalent scheme for small refugial sites according to their function and capacity, based on the relict species concept. This approach and proposed terminology is tested on the example of two plant species with different pattern of the long term range dynamics. Our paper highlights the importance of sites harboring 'trailing-edge' young relicts for the future long-term persistence of the species (as old relicts) under unfavorable regional conditions. By considering the age gradients of small refugial sites it is possible to reveal community interactions, species traits or genes that drive the responses of biota to climate changes.
\end{abstract}

Keywords Climate change $\cdot$ Microrefugia $\cdot$ Perfugia $\cdot$ Refugia $\cdot$ Species range dynamics $\cdot$ Species extinction

Marcin Kiedrzyński

marcin.kiedrzynski@biol.uni.lodz.pl

1 Department of Geobotany and Plant Ecology, Faculty of Biology and Environmental Protection, University of Lodz, Lodz, Poland

2 Department of Applied Ecology, Faculty of Biology and Environmental Protection, University of Lodz, Lodz, Poland

3 European Regional Centre for Ecohydrology of the Polish Academy of Sciences, Lodz, Poland 


\section{Introduction}

Refugia are places where species persist and from where they can potentially expand under changing environmental conditions (Keppel et al. 2012); they especially facilitate the survival of organisms during climate oscillations. The occurrence and location of longterm refugia determine the current patterns of biodiversity on Earth (Willis and Whittaker 2000). Increasing numbers of publications examine the location, age and role of the refugial areas in given regions (Keppel and Wardell-Johnson 2012; Gavin et al. 2014). The importance of the refugial debate is certain to intensify in response to species extinctions which have already been observed, and those expected to be caused by anthropogenic climate change (Willis and Whittaker 2000; Gavin et al. 2014 and cited).

General patterns and associated terms regarding refugia have been recognised in the last decade (e.g. Bhagwat and Willis 2008; Bennet and Provan 2008; Ashcroft 2010; Keppel et al. 2012; Gavin et al. 2014; Birks 2015). Microrefugia (sensu Rull 2009), small areas where species survive outside their core range, have an important status. Their occurrence accounts for the so-called 'Reid's paradox' referring to the incompatibility between the paleoecologically-investigated speed of range expansions during migration from macrorefugia (large areas where the species occur during unfavourable periods) and the species dispersal capacities (Rull 2009, 2010). Microrefugia can play a crucial role as potential sites from which species recovery its abundance in the region (e.g. Magri 2008). However, it seems that after long-term isolation, microrefugial populations can also 'give birth to new species' (Hampe and Petit 2005).

The refugium concept, which came from the paleobiological studies, has been adopted by Biogeography, Evolutionary Ecology, Phylogeography, conservation planning and species distribution modelling, and as a result, the same terms have different ranges of meaning depending on the context. What more, the potential of fine-grain modelling as a new technique of species range prediction have pushed authors to use increasingly diverse and rich terminology.

In the opinion of most authors, the term microrefugia is connected with long-term processes (on the evolutionary time scale) but other small sites or habitats, which play the role of 'safe haven' in the shorter time scale (the ecological time scale) should be excluded from the refugium concept (Stewart et al. 2010; Keppel et al. 2012). In our opinion, this approach can result in the loss of linkage between ecological and evolutionary processes which taking place in different phases of range restriction. Mee and Moore (2014) postulate that the processes surrounding the appearance and persistence of refugial populations should be analysed from both ecological and evolutionary perspectives. Some solutions have been presented recently in inspiring papers by Hannah et al. (2014), Keppel and Wardell-Johnson (2015) and Keppel et al. (2015); however, these papers differ with regard to their interpretation of the described phenomena. Moreover, the relationship between the processes occurring during extinction and refugial phases of the species range dynamics, is not clearly visible. Therefore, some improvements are needed to develop a coherent concept.

\section{The road to microrefugia: linking ecology and evolution}

In contrast to presence in the main range, the occurrence of species in microrefugia is influenced by: isolation, small population size, reduced within-population genetic diversity, high level of genetic diversity among populations and lower ecological diversity of 
associated communities (Hampe and Petit 2005; Mee and Moore 2014). However, the small geographical area of microrefugia does not necessarily imply a small effective population size, and microrefugial populations may even have a relatively high level of genetic diversity (Bai and Zhang 2015). Therefore, the ecological and evolutionary consequences of the microrefugial phase in population dynamics are thought to encompass the evolution of the mating system, the promotion of local adaptations, and the promotion of ecological divergence and coevolution (Mee and Moore 2014).

The 'road' to the above consequences needs time and relatively stable conditions (Woolbright et al. 2014). Such stabilization can occur after extinction events and range restriction. The latter are characterized by the creation of new relationships with changing abiotic and biotic factors (Hampe and Petit 2005; Hylander and Ehrlén 2013). Populations are typified then by a reduced gene flow and smaller size, and new interactions in impoverished communities can be established (Mee and Moore 2014). The extinction phase is a dynamic period when preparation of the ecological basis for the future long-time species persistence in the region can occur.

The concept of 'trailing-edge relicts' (young relict populations) and 'stabilized relicts' (old relict populations) recognized by Hampe and Petit (2005) and developed by Woolbright et al. (2014) clearly corresponds to the above processes. Younger 'trailing edge' populations often occur near the core range of the species and have recently become isolated. In contrast, the oldest 'stable' climate relicts have persisted for a long time over changing climate conditions (Hampe and Petit 2005; Fig. 1). If species interactions can be expected to vary among these differently-aged climate relicts in the same way that population patterns and processes vary, the differences between trailing edge and stable climate relicts might reveal ecologically and evolutionarily significant patterns, such as community stability and selective pressure. In addition, novel species interactions can result in the phenomenon of the genetic switch of species or coevolution over time (Woolbright et al. 2014; Fig. 1).

In contrast, the concept of refugia includes rather places characterized by habitat conditions which have long-term stability e.g. microrefugia or cryptic refugia as described by Rull (2009), Stewart and Lister (2001) and Keppel et al. (2012). The habitats which exist in a shorter, ecological time scale (Table 1) are usually excluded from the concept. In our opinion, this approach excludes the important phase of the establishment of microrefugia from the discussion. The process which leads to the establishment of microrefugia should be taken into account also in the refugial concept, and the distinction between places where the trailing-edge relicts and stabile relicts exists is needed.

Keppel and Wardell-Johnson (2015) propose the naming of such locations as refugia with different refugial capacities. Although this approach is doubtlessly useful and deserves much consideration, the question arises whether the all sites of vanishing species may accurately be labelled refugia. As we describe above, microrefugial populations are analogous to 'stabilized relicts'. Moreover, an essential element of refugium ontology is the potential for long-term existence of the harbored population and the possibility for the species to expand after the environmental conditions improve. Hence, the term 'refugia' should be exclusive for long-term stabile conditions and formed biotic interactions, which are not already in the phase of 'trailing-edge relicts'. Finally, while retrospective analysis is suitable for the recognition of real refugia, where stabilized relicts can exist, it is often unclear whether the currently-observed location of the species is a long-lasting refugium or only its temporary site.

Based on the above arguments and to recognize sites where the processes appropriate for the 'trailing-edge relicts' occur, we propose to introduce the Latinised term 'perfugium' 


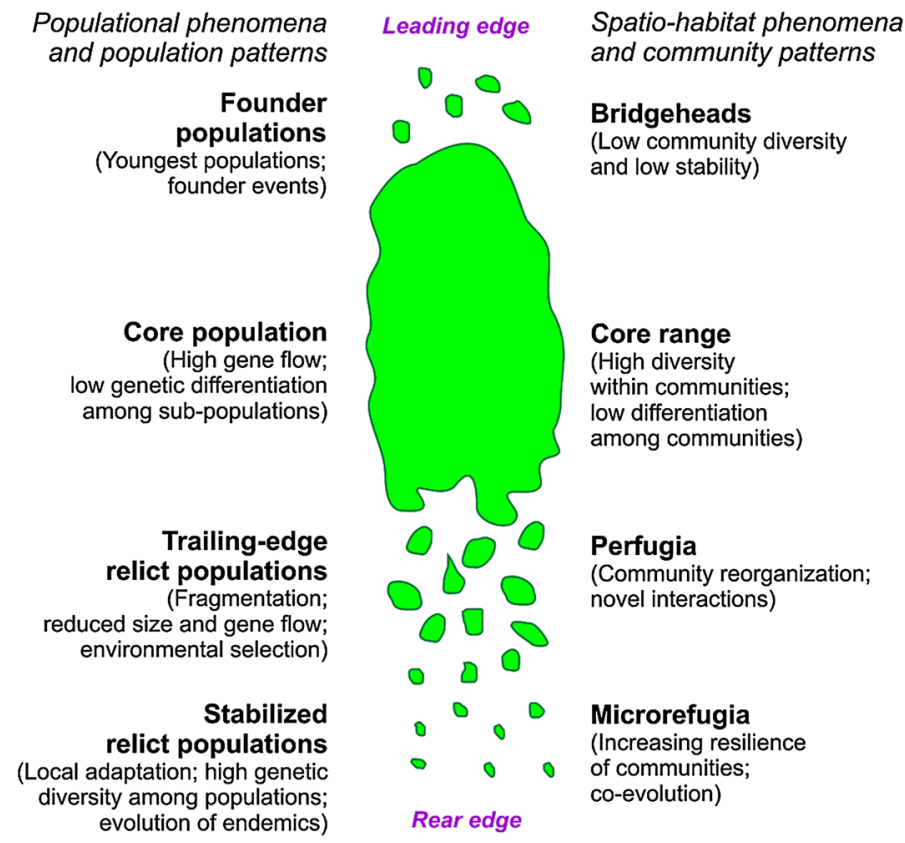

Fig. 1 Populational and spatio-habitat phenomena and some associated patterns according to hypothetical species range shift. Definitions and explanations can be found in the text and Table 1. The schema is inspired by Hampe and Petit (2005) and Woolbright et al. (2014)

( a place to flee to, a shelter, asylum, refuge) to the refugial concept; we define this as a small area/habitat patch where the species can survive during the process of extinction and where biotic/habitat interactions necessary for further long-term persistence in the region under unfavorable environmental conditions can establish. It is a general term which does not assume a priori specific effects of changes, nor the cause of the decrease of range and abundance of the species. The concept of perfugia can link the short and the long timescales in the analysis of ecological and genetic processes taking place during range shifts.

From the above perspective, the basic term 'microrefugium', after an adequate modification of Rull's (2009) definition, could be now understood as: a small area/habitat patch in the region where species survive and can benefit from evolutionary processes during isolation and relative stable conditions after range shift or restriction, and from where they can potentially expand following the improvement of environmental conditions.

\section{The populational or spatio-habitat nature of refugial phenomena}

Hannah et al. (2014) introduce interesting terms for small range elements, such as 'holdouts', 'microrefugia' and 'stepping-stones' in a population-centered meaning (Table 1). The authors introduce these notions to describe their different function during species range dynamics. However, as 'refugium' is most widely used in its spatio-habitat context (e.g. Rull 2009; Ashcroft 2010; Keppel et al. 2012; Gavin et al. 2014; Birks 2015 and others), the usage of 'micro-refugium' as a population-centered term could be misleading. Hannah et al. (2014) use these terms with regard to species distribution modelling. However, even if species-specific ecological and biological predictors are used (Cassini 
Table 1 Basic terms used in the refugial debate according to their spatio-temporal scales and populational or spatio-habitat meanings

\begin{tabular}{|c|c|c|c|c|}
\hline Term & $\begin{array}{l}\text { Nature of } \\
\text { the } \\
\text { phenomenon }\end{array}$ & $\begin{array}{l}\text { Environmental } \\
\text { change/species } \\
\text { distribution change }\end{array}$ & Description & $\begin{array}{l}\text { Chosen } \\
\text { references }\end{array}$ \\
\hline
\end{tabular}

Evolutionary time scale

Spatial scale undetermined

\begin{tabular}{|c|c|c|c|c|}
\hline Refugium & $\begin{array}{l}\text { Spatio- } \\
\text { habitat }\end{array}$ & $\begin{array}{l}\text { Climate change, } \\
\text { range shift }\end{array}$ & $\begin{array}{l}\text { Habitat that components of } \\
\text { biodiversity retreat to, } \\
\text { persist in and can } \\
\text { potentially expand from } \\
\text { under changing } \\
\text { environmental conditions }\end{array}$ & $\begin{array}{l}\text { Keppel et al. } \\
\text { (2012) }\end{array}$ \\
\hline Cryptic refugium & $\begin{array}{l}\text { Spatio- } \\
\text { habitat }\end{array}$ & $\begin{array}{l}\text { Climate change, range } \\
\text { shift }\end{array}$ & $\begin{array}{l}\text { Refugium situated at } \\
\text { different areas than would } \\
\text { normally be expected; } \\
\text { climatic island in which } \\
\text { conditions differ } \\
\text { favourably from the } \\
\text { surrounding areas; name is } \\
\text { based on inability of } \\
\text { current paleobiological } \\
\text { techniques to detect that } \\
\text { past local populations; } \\
\text { however according to the } \\
\text { authors small size is not } \\
\text { integral to its definition }\end{array}$ & $\begin{array}{l}\text { Stewart and } \\
\text { Lister } \\
(2001) \\
\text { Stewart } \\
\text { et al. } \\
\text { (2010) }\end{array}$ \\
\hline \multicolumn{5}{|l|}{ Large spatial scale } \\
\hline $\begin{array}{l}\text { Macrorefugium } \\
\text { (classic } \\
\text { refugium) }\end{array}$ & $\begin{array}{l}\text { Spatio- } \\
\text { macro- } \\
\text { habitat }\end{array}$ & $\begin{array}{l}\text { Climate change, } \\
\text { range shift }\end{array}$ & $\begin{array}{l}\text { Main (core) area where the } \\
\text { species survive during the } \\
\text { unfavourable } \\
\text { environmental (climatic) } \\
\text { conditions }\end{array}$ & $\begin{array}{l}\text { Bennet and } \\
\text { Provan } \\
\text { (2008), } \\
\text { Rull (2009) }\end{array}$ \\
\hline \multicolumn{5}{|l|}{ Small spatial scale } \\
\hline Microrefugium & $\begin{array}{l}\text { Spatio- } \\
\text { habitat }\end{array}$ & $\begin{array}{l}\text { Climate change, } \\
\text { range shift }\end{array}$ & $\begin{array}{l}\text { A small area/habitat patch } \\
\text { in the region where } \\
\text { species survive and can } \\
\text { benefit from evolutionary } \\
\text { processes during isolation } \\
\text { and relative } \\
\text { stable conditions after } \\
\text { range shift or restriction, } \\
\text { and from where they can } \\
\text { potentially expand } \\
\text { following the } \\
\text { improvement of } \\
\text { environmental conditions }\end{array}$ & $\begin{array}{l}\text { Rull (2009), } \\
\text { changed }\end{array}$ \\
\hline Microrefugium & Populational & $\begin{array}{l}\text { Climate change, range } \\
\text { shift }\end{array}$ & $\begin{array}{l}\text { Isolated population surviving } \\
\text { in unusual micro- climates } \\
\text { relative to the surrounding } \\
\text { landscape }\end{array}$ & $\begin{array}{l}\text { Hannah et al. } \\
\text { (2014) }\end{array}$ \\
\hline
\end{tabular}


Table 1 continued

\begin{tabular}{|c|c|c|c|c|}
\hline Term & $\begin{array}{l}\text { Nature of } \\
\text { the } \\
\text { phenomenon }\end{array}$ & $\begin{array}{l}\text { Environmental } \\
\text { change/species } \\
\text { distribution change }\end{array}$ & Description & $\begin{array}{l}\text { Chosen } \\
\text { references }\end{array}$ \\
\hline $\begin{array}{l}\text { High capacity } \\
\text { refugium } \\
\text { (microrefugium) }\end{array}$ & $\begin{array}{l}\text { Spatio- } \\
\text { habitat }\end{array}$ & $\begin{array}{l}\text { Climate change, range } \\
\text { shift }\end{array}$ & $\begin{array}{l}\text { Small refugium which retain } \\
\text { environmental conditions } \\
\text { not available in the } \\
\text { surrounding landscape and } \\
\text { facilitate the long-term } \\
\text { persistence of populations } \\
\text { when the surrounding } \\
\text { landscape cannot; it have a } \\
\text { greater capacity as other } \\
\text { small refugia }\end{array}$ & $\begin{array}{l}\text { Keppel and } \\
\text { Wardell- } \\
\text { Johnson } \\
(2015)\end{array}$ \\
\hline \multicolumn{5}{|c|}{$\begin{array}{l}\text { Ecological to evolutionary time scale } \\
\text { Small spatial scale }\end{array}$} \\
\hline Holdout & Populational & $\begin{array}{l}\text { Climate change, range } \\
\text { restriction }\end{array}$ & $\begin{array}{l}\text { Isolated population that } \\
\text { survive in unusual } \\
\text { microclimate for a limited } \\
\text { duration; it can persistence } \\
\text { for a limited time under } \\
\text { deteriorating climates }\end{array}$ & $\begin{array}{l}\text { Hannah et al. } \\
\text { (2014) }\end{array}$ \\
\hline Perfugium & $\begin{array}{l}\text { Spatio- } \\
\text { habitat }\end{array}$ & $\begin{array}{l}\text { Climate change, } \\
\text { biotic interaction, } \\
\text { abundance } \\
\text { restriction, range } \\
\text { restriction }\end{array}$ & $\begin{array}{l}\text { Small area/habitat patch } \\
\text { where the species can } \\
\text { survive during the process } \\
\text { of extinction and where } \\
\text { biotic/habitat interactions } \\
\text { necessary for further } \\
\text { long-term persistence in } \\
\text { the region under } \\
\text { unfavorable } \\
\text { environmental conditions } \\
\text { can establish }\end{array}$ & $\begin{array}{l}\text { Introduced } \\
\text { in the } \\
\text { paper }\end{array}$ \\
\hline Stepping stones & Populational & $\begin{array}{l}\text { Climate change, range } \\
\text { expansion }\end{array}$ & $\begin{array}{l}\text { A series of populations } \\
\text { occupying successive } \\
\text { microclimates that have a } \\
\text { role in mediating the range } \\
\text { shift of a species in } \\
\text { response to climate change; } \\
\text { occupy microclimates } \\
\text { successively to facilitate } \\
\text { range shifts }\end{array}$ & $\begin{array}{l}\text { Hannah et al. } \\
\text { (2014) }\end{array}$ \\
\hline Bridgehead & $\begin{array}{l}\text { Spatio- } \\
\text { habitat }\end{array}$ & $\begin{array}{l}\text { Climate change, } \\
\text { range expansion }\end{array}$ & $\begin{array}{l}\text { Small areas occurring } \\
\text { forward of the core range } \\
\text { during its shift in the } \\
\text { region, where the } \\
\text { populations mediating in } \\
\text { the range expansion could } \\
\text { exist }\end{array}$ & $\begin{array}{r}\text { Faliński } \\
(2000)\end{array}$ \\
\hline
\end{tabular}


Table 1 continued

\begin{tabular}{lllll}
\hline Term & $\begin{array}{l}\text { Nature of } \\
\text { the } \\
\text { phenomenon }\end{array}$ & $\begin{array}{l}\text { Environmental } \\
\text { change/species } \\
\text { distribution change }\end{array}$ & Description & $\begin{array}{c}\text { Chosen } \\
\text { references }\end{array}$ \\
\hline $\begin{array}{l}\text { Low capacity } \\
\text { refugium } \\
\text { (stepping stone, } \\
\text { holdouts) }\end{array}$ & $\begin{array}{c}\text { Spatio- } \\
\text { habitat }\end{array}$ & $\begin{array}{c}\text { Climate change, range } \\
\text { restriction or } \\
\text { expansion }\end{array}$ & $\begin{array}{l}\text { Small refugium which retain } \\
\text { environmental conditions } \\
\text { not available in the } \\
\text { surrounding landscape but } \\
\text { it facilitate only the short- }\end{array}$ & $\begin{array}{c}\text { Wardell- } \\
\text { term persistence of }\end{array}$ \\
& & $\begin{array}{l}\text { populations; it have a low } \\
\text { refugial capacity }\end{array}$ & \\
\hline
\end{tabular}

Terms in bold are proposed to be used for the clarification of the concept of refugia and the species range dynamics

2011; Kiedrzyński et al. 2017), modeling only defines the areas with a high probability of population occurrence, not the occurrence of the populations themselves. By its very nature, a modelled ecological niche does not include such population-specific properties as demographics or genetic structure. Therefore, it is more applicable to use the terms associated with refugia of small geographic extent in the spatio-habitat sense (Fig. 1; Table 1).

Mosblech et al. (2011) considered the concept of microrefugia as a long-term variant of metapopulation theory in ecological and biogeographical dynamics, in which environmental stability supersedes gene flow in determining species survival. In this context, and according to the island biogeography theory (MacArthur and Wilson 1967), we can consider microrefugia (or perfugia) as patches of suitable habitats which may or may not be inhabited by relict populations at a certain period. The occupation of suitable sites which can play a role in species range shift depends in a meaningful way on the dispersal effectiveness (Robillard et al. 2015); hence, some sets of suitable sites can only play a potential role. As mentioned above, in regions where general conditions are projected to became unsuitable for the analyzed taxa, it is only possible to model potential, locallysuitable sites (e.g. potential perfugia or microrefugia, depending on the phase of range restriction).

\section{The role of perfugia and microrefugia during the species range dynamics}

During unfavorable changes in the region, species extinction occurs and increasing numbers of isolated localities are established (Hylander and Ehrlén 2013). These can be termed perfugia (Fig. 2). Over time, unsuitable abiotic conditions, degenerative genetic processes or lack of adequate (new) ecological configurations can result in successive extinctions in some of these sites. The occurrence of the species in the region becomes possible only in perfugia with the highest refugial capacity, i.e. where favorable interactions have been established. These can be termed microrefugia. The phase in which the species only occurs in microrefugia in the region could be called the 'microrefugial equilibrium' (Fig. 2a), when the long-term existence of the species could cause such evolutionary processes as local adaptation, evolution of endemics or co-evolution.

We can also assume that in some cases, the microrefugial equilibrium phase can be disrupted by subsequent environmental changes, such as climatic ones. We demonstrate the 
(a)

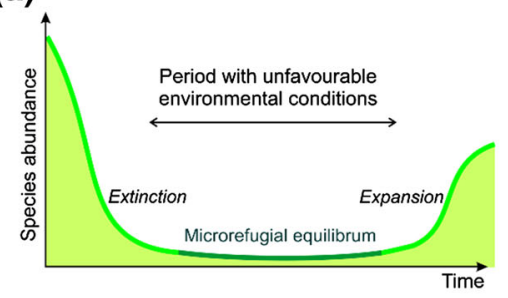

(b)

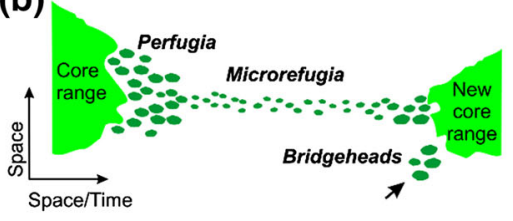

(c)

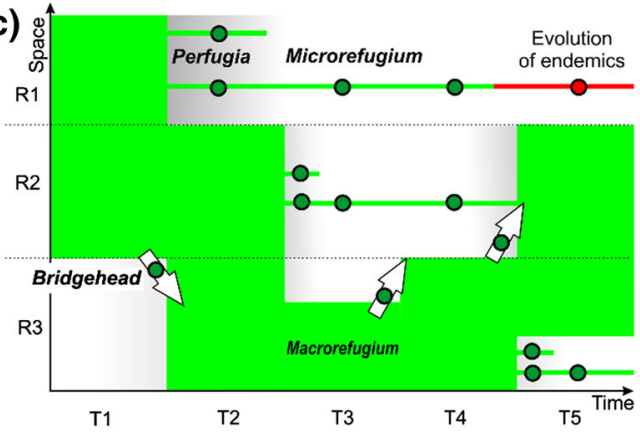

Low Suitability of enviroment

Points in space and time

of enviroment

Core range

R1-R3 Geographical regions

T1-T5 Periods with different environmental conditions

Fig. 2 Long-term species response to environmental changes in the region according to the refugia concept, visible as: a changes of species abundance in the region; $\mathbf{b}$ restriction and recovery of the species range in the region and $\mathbf{c}$ range shift across neighbouring regions. Definitions and explanations can be found in the text and Table 1. Schematics are inspired by: Bennet and Provan (2008), Hylander and Ehrlén (2013) and Keppel and Wardell-Johnson (2015)

existence of this pattern on the example of the two plants Pulsatilla vernalis and Kunzea pulchella in a later part of the paper.

Following 'microrefugial equilibrium', the species may return to abundance in the region as environmental conditions improve (Fig. 2). In some cases, this recovery could be accelerated by migration from the macrorefugium (Fig. 2b, c). On this leading edge of the species range, small elements are represented by isolated populations established by founder events. According to Faliński (2000), we suggest the term 'bridgeheads' here, which could be defined as: small areas occurring forward of the core range during its shift in the region, where the populations mediating in the range expansion could exist.

\section{Multiple origin and dynamics of refugial sites: the case of Pulsatilla vernalis}

Pulsatilla vernalis (L.) Mill. (Ranunculaceae) is a model, cold-adapted species, which occurs throughout most of the European alpine systems, as well as the Scandinavian chain. The species occurs also in the Central European lowlands (Fig. 3a). Phylogeographical studies suggest the presence of a higher diversity of haplotypes in mountain areas compared with those in lowland populations (Fig. 3b), which supports the claim that P. vernalis originated in alpine habitats and subsequently colonized the lowland areas in Central Europe during glacial periods also in Scandinavia following the Last Glacial Maximum (LGM) (Ronikier et al. 2008).

The current (interglacial) core range of that cold-adapted species is restricted to the Alps, Pyrenees, Cantabrian Mountains and Scandinavian chain, which could be regarded as interglacial macrorefugia (Fig. 3).

Other locations in mountains, such as the Massif Central, the Sudetes, the Tatra Mountains and the mountains on the Balkan Peninsula are isolated and represent the surviving populations of the previous wider range of the species. The existence and isolation of the $P$. vernalis in some of these mountain areas may last for a long time, which is 


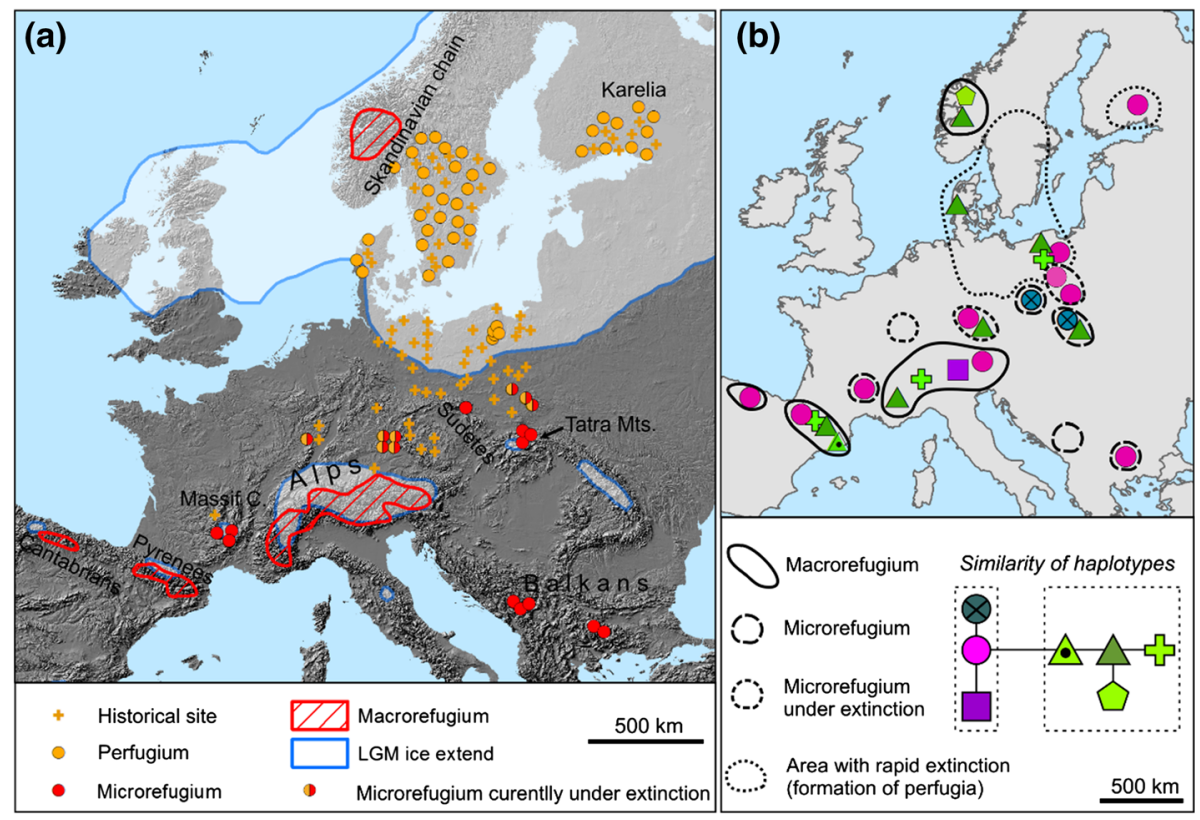

Fig. 3 Interglacial (Holocene) refugia of the cold-adapted plant Pulsatilla vernalis in Europe with the indication of the current macrorefugia, microrefugia and perfugia; a distribution of the species and its historical sites according to Grzyl et al. (2014) changed; b distribution and minimum spanning tree of cpDNA haplotypes according to Ronikier et al. (2008), generalized

visible in the presence of the unique cpDNA haplotypes (Fig. 3b). These locations could be regarded as interglacial mountain microrefugia. Mountain conditions seem to have guaranteed maintenance of appropriate habitats and long-lasting persistence of the microrefugial equilibrium.

Genetic data has also shown that the presence of $P$. vernalis in the lowlands of Central Europe is not only the result of a recent (Holocene) post-glacial colonization from the Alpine refugia (Ronikier et al. 2008); it indicates the possibility of an earlier migration from mountain to lowland areas and survival in northern periglacial microrefugia, located between the Alps in the south and the Pleistocene ice sheet in the north. During the early Holocene, the lowland populations from territories located now in the southern Poland and southern Germany might have been the sources of further northward migration (Ronikier et al. 2008). Some of the isolated populations have survived until now and can be considered as lowland microrefugia (Fig. 3). However, those current microrefugial populations are declining as a result of intensive forestry and successional changes in the plant communities accelerated by the anthropogenic eutrophication of soils and climate change (Betz et al. 2013; Grzyl et al. 2014).

Species extinction has been observed in the last decades in the northern part of the lowlands, especially within the extent of the Last Glacial Maximum (Grzyl and Ronikier 2011; Sandström et al. 2017). The previously compact part of the lowland range was fragmented, resulting in the formation of increasing numbers of isolated populations (Fig. 3). Although the sites where the species lived despite widespread extinctions cannot be accurately termed microrefugia, they can be identified as perfugia (Fig. 3). 
As we mentioned above, the species probably occurred during earlier climate oscillations in the lowland microrefugia between the mountains and the northern ice extent. Hence, some mechanisms and traits proved to be effective in maintaining the species in lowlands during the climate oscillations. For example, the species is sensitive to competition from grasses, dwarf shrubs, mosses and lichens (Betz et al. 2013; Zielińska et al. 2016; Sandström et al. 2017), therefore, lowland populations tend to grow on nutrient-poor soils where the threat from other community members is much lower. Moreover, habitat factors suitable for species regeneration in the lowlands include cyclic disturbances such as fires (Sandström et al. 2017). Originally being a high-mountain plant, $P$. vernalis depends also on a relatively high level of humidity; therefore, in the lowlands, new plants appear when appropriate level of precipitation in summer occurs, what happens once every few years (Grzyl et al. 2014). Recently these adaptations have not been enough to maintain the species in the northern parts of the lowlands. The range of the species is heading towards significant restriction (or disappearance) in the region, mostly caused by changes in the structure of plant communities caused by habitat eutrophication (Sandström et al. 2017). In the anthropogenic landscape of northern Poland, the species now grows mostly on the edges of forest roads and railways (Zielińska et al. 2016), which can be identified as the current perfugial habitats. The question about the possibility of the long-term persistence of $P$. vernalis in that sites is open. As shown in example of $P$. vernalis, the introduction of the term 'perfugium' has substantial and practical value from the perspective of enabling a comprehensive analysis of the long-term changes in the species range.

\section{Fluctuation dynamics within microrefugia: the case of Kunzea pulchella}

Kunzea pulchella Lindl. (Myrtaceae) is a bird-pollinated evergreen shrub endemic for the South-West Australian Floristic Region and adjacent Eremean province (Tapper et al. 2014). The species actually grows within granite outcrops where relatively moist microhabitats occur. The authors suggest that the wide physiological tolerances and traits typical of specialists of the granite environment made the species resistant to changes in climate from arid to more mesic conditions. Phylogeographic patterns emerging from recent studies show that as the climate became drier during the Pleistocene glacial phases, some species ranges contracted to local refugia such as granite outcrops and persisted in them (Byrne 2008). Analyses of narrow-range granite endemics have uncovered patterns of persistence, prolonged isolation and divergence (e.g. Sampson et al. 1988; Byrne and Hopper 2008), rather than contraction/local extinction and recolonization. The more common and geographically widespread $K$. pulchella was also recently described as displaying a pattern of contraction and expansion only within particular outcrops but not between them (Tapper et al. 2014).

The question arises as to the type of phenomena observed in the case of $K$. pulchella in the context of the refugia concept and proposed terminology. Firstly, the genetic pattern within the actual restricted range of the species, typified by high divergence among populations (Tapper et al. 2014), suggests that multiple microrefugia are present, characterized by the long-term isolation between populations rather than a single macrorefugium. Secondly, molecular dating, showing the divergence among populations (Tapper et al. 2014), indicates a correlation with the major aridification phases of the mid-Pleistocene; this is similar to the trends observed in other regional endemics (Byrne 2008) and generally reflects a changes in oscillation patterns during the Milankovitch cycles.

Taking the above into account, we can assume that the early Pleistocene is probably the period when the species range restriction occurred, and when some habitats became 
perfugia. During the perfugial phase, favourable ecological relations were established which allowed further species survival within granite outcrops. Since that time, the species has been observed in isolated populations in a microrefugial equilibrium within rocky outcrops, thus providing genetic divergence the time to evolve. Currently occurring populations can be defined as stabilized relict populations whose local abundance can fluctuate only within granite outcrops according to climate changes as suggested by Tapper et al. (2014); this can be identified as the fluctuation dynamics within microrefugia.

The example of $K$. pulchella shows that in some cases, the microrefugial phase could take place on even a geological time scale, and can result in the evolution of divergences in isolated microrefugia without the establishment of a macrorefugium.

\section{Concluding remarks}

The linking of ecological and evolutionary processes in the refugia concept is fundamental for understanding the species response to climate change. The study of the action of the 'trailing-edge' relict populations occurring in perfugia can reveal the reasons for the longterm persistence of the species despite unfavourable conditions. In microrefugia, the populations benefit from the processes which previously took place in perfugia. The patterns defined in this paper also link the concepts of 'relict species' and 'refugia', which before now, have usually been recognized as separate notions. In this sense, our analysis follows the concept of Mee and Moore (2014), who express the need to emphasize the role of refugial populations, and the importance of microrefugia, in the evolution of species and populations. The introduction of the term 'perfugia', as a spatio-temporal linkage between species core range and its microrefugial sites, highlights the importance of the phase during which the mechanisms allowing future existence of the species in the region are put into action. The study of these phenomena can reveal community interactions, species traits or genes that drive the responses of biota to changes in climate (Woolbright et al. 2014).

The age gradients in relict populations and their habitats are useful markers for observing patterns and processes such as community disassembly or the evolution of novel interactions between species over large spatial and temporal scales. Such topics require further investigation using community and population ecology and genetics, supported by common garden experiments on individuals from perfugia and microrefugia.

Acknowledgements Our generalized model and theoretical conception are the result of the experience gained during research financially supported by the University of Łódź.

Open Access This article is distributed under the terms of the Creative Commons Attribution 4.0 International License (http://creativecommons.org/licenses/by/4.0/), which permits unrestricted use, distribution, and reproduction in any medium, provided you give appropriate credit to the original author(s) and the source, provide a link to the Creative Commons license, and indicate if changes were made.

\section{References}

Ashcroft MB (2010) Identifying refugia from climate change. J Biogeogr 37:1407-1413

Bai W-N, Zhang D-Y (2015) Small effective population size in microrefugia? J Systematics Evol 53(2):163-165

Bennet KD, Provan J (2008) What do we mean by 'refugia'? Quat Sci Rev 27:2449-2455 
Betz C, Scheuerer M, Reisch C (2013) Population reinforcement-a glimmer of hope for the conservation of the highly endangered spring pasque flower (Pulsatilla vernalis). Biol Conserv 168:161-167

Bhagwat SA, Willis KJ (2008) Species persistence in northerly glacial refugia of Europe: a matter of chance or biogeographical traits? J Biogeogr 35:464-482

Birks HJB (2015) Some reflections on the refugium concept and its terminology in historical biogeography, contemporary ecology and global-change biology. Biodiversity 16(4):196-212

Byrne M (2008) Evidence for multiple refugia at different time scales during the Pleistocene climatic oscillations in southern Australia inferred from phylogeography. Quat Sci Rev 27:2576-2585

Byrne M, Hopper SD (2008) Granite outcrops as ancient islands in old landscapes: evidence from the phylogeography and population genetics of Eucalyptus caesia (Myrtaceae) in Western Australia. Biol J Linn Soc 93:177-188

Cassini MH (2011) Ecological principles of species distribution models: the habitat matching rule. J Biogeogr 38:2057-2065

Faliński JB (2000) The interpretation of contemporary vegetation transformations on the basis of the theories of synanthropization and syndynamics. In: Jackowiak B, Żukowski W (eds) Mechanisms of anthropogenic changes of the plant cover, No. 10. University of Poznań, Poznań, pp 9-30

Gavin DG, Fitzpatrick MC, Gugger PF et al (2014) Climate refugia: joint inference from fossil records, species distribution models and phylogeography. New Phytol 204:37-54

Grzyl A, Ronikier M (2011) Pulsatilla vernalis (L.) Mill. (Ranunculaceae) in the Polish lowlands: contribution to the assessment of current population resources of a strongly declining species. Pol Bot $\mathbf{J}$ 56(2):185-194

Grzyl A, Kiedrzyński M, Zielińska KM, Rewicz A (2014) The relationship between climatic conditions and generative reproduction of a lowland population of Pulsatilla vernalis: the last breath of a relict plant or a fluctuating cycle of regeneration? Plant Ecol 215(4):457-466

Hampe A, Petit RJ (2005) Conserving biodiversity under climate change: the rear edge matters. Ecol Lett 8:461-467

Hannah L, Flint L, Syphard AD, Moritz MA, Buckley LB, McCullough IM (2014) Fine-grain modelling of species' response to climate change: holdouts, stepping-stones, and microrefugia. Trends Ecol Evol 29:390-397

Hylander K, Ehrlén J (2013) The mechanisms causing extinction debts. Trends Ecol Evol 28:341-346

Keppel G, Wardell-Johnson GW (2012) Refugia: keys to climate change management. Glob Change Biol 18(8):2389-2391

Keppel G, Wardell-Johnson GW (2015) Refugial capacity defines holdouts, microrefugia and steppingstones: a response to Hannah et al. Trends Ecol Evol 30:233-234

Keppel G, Van Niel KP, Wardell-Johnson GW, Van Niel K, Yates CJ, Byrne M, Mucina L, Schut AGT, Hopper SD, Franklin SE (2012) Refugia: identifying and understanding safe havens for biodiversity under climate change. Glob Ecol Biogeogr 21:393-404

Keppel G, Mokany K, Wardell-Johnson GW, Phillips B, Welbergen J, Reside AE (2015) The capacity of refugia for conservation planning under climate change. Front Ecol Environ 13:106-112

Kiedrzyński M, Zielińska KM, Rewicz A, Kiedrzyńska E (2017) Habitat and spatial thinning improve the Maxent models performed with incomplete data. J Geophys Res Biogeosci. doi:10.1002/ 2016JG003629

MacArthur RH, Wilson EO (1967) The theory of island biogeography. Princeton University Press, Princeton, NJ

Magri D (2008) Patterns of post-glacial spread and the extent of glacial refugia of European beech (Fagus sylvatica). J Biogeogr 35(3):450-463

Mee JA, Moore J-S (2014) The ecological and evolutionary implications of microrefugia. J Biogeogr 41(5):837-841

Mosblech NAS, Bush MB, Van Woesik R (2011) On metapopulations and microrefugia: palaeoecological insights. J Biogeogr 38(3):419-429

Robillard CM, Coristine LE, Soares RN, Kerr JT (2015) Facilitating climate-change-induced range shifts across continental land-use barriers. Conserv Biol 29(6):1586-1595

Ronikier M, Costa A, Aguilar JF, Feliner GN, Küpfer P, Mirek Z (2008) Phylogeography of Pulsatilla vernalis (L.) Mill. (Ranunculaceae): chloroplast DNA reveals two evolutionary lineages across central Europe and Scandinavia. J Biogeogr 35:1650-1664

Rull V (2009) Microrefugia. J Biogeogr 36:481-484

Rull V (2010) On microrefugia and cryptic refugia. J Biogeogr 37:1623-1627

Sampson JF, Hopper SD, James SH (1988) Genetic diversity and conservation of Eucalyptus crucis Maiden. Aust J Bot 36:460-477 
Sandström A, Svensson BM, Milberg P (2017) An example of how to build conservation evidence from case studies: fire and raking to enhance Pulsatilla vernalis populations. J Nat Conserv 36:58-64

Stewart JR, Lister AM (2001) Cryptic northern refugia and the origins of the modern biota. Trends Ecol Evol 16(11):608-613

Stewart JR, Lister AM, Barnes I, Dalén L (2010) Refugia revisited: individualistic responses of species in space and time. Proc Biol Sci R Soc 277(1682):661-671

Tapper SL, Byrne M, Yates CJ, Keppel G, Hopper SD, Van Niel K, Schut AGT, Mucina L, Wardell-Johnson GW (2014) Prolonged isolation and persistence of a common endemic on granite outcrops in both mesic and semi-arid environments in south-western Australia. J Biogeogr 41(11):2032-2044

Willis KJ, Whittaker RJ (2000) The refugial debate. Science 287:1406-1407

Woolbright SA, Whitham TG, Gehring CA, Allan GJ, Bailey JK (2014) Climate relicts and their associated communities as natural ecology and evolution laboratories. Trends Ecol Evol 29:406-416

Zielińska KM, Kiedrzyński M, Grzyl A, Rewicz A (2016) Forest roadsides harbour less competitive habitats for a relict mountain plant (Pulsatilla vernalis) in lowlands. Sci Rep 6:31913 